\title{
Effects of Foreign Banks Entry on the Operations of Domestic Banks-Empirical Evidence from Ghana
}

\author{
Isaac Boadi $^{1}$ \\ ${ }^{1}$ Open university-Heerlen (Holland), Ghana \\ Correspondence: Isaac Boadi, Open university-Heerlen (Holland), Ghana. E-mail: kwameperp@yahoo.co.uk
}

Received: October 11, 2015

Accepted: October 28, $2015 \quad$ Online Published: November 25, 2015

doi:10.5539/ijbm.v10n12p54

URL: http://dx.doi.org/10.5539/ijbm.v10n12p54

\begin{abstract}
The purpose of the research is to examine the effects of foreign banks entry on the operations of domestic banks in Ghana. The study employs panel data analysis to examine the effects of foreign banks entry on the operations of domestic banks in Ghana. Data for the study were drawn from the databases of Ghana Association of Bankers, Ghana Statistical Service and Bank of Ghana over the period from 1997 to 2014. Results of the study reveal that entry of foreign banks is significantly associated with increase in net interest income and return on assets. Among the bank-specific determinant variables, only deposit, liquidity and capital reveal statistically significant association with bank profitability. The research could not include more qualitative factors. Future research could include more qualitative factors, for example, management leadership style with the quantitative factors and test for long run effects. The main value of this paper is the analysis of new empirical evidence on the effect of foreign banks entry on the operations of domestic banks operations.
\end{abstract}

Keywords: entry of foreign banks, domestic banking

\section{Introduction}

The presence of foreign banks in emerging economies is an aged long global issue (Domanski, 2005). For some years now, governments and policy makers of emerging market economies have switched away from a restrictive monetary and financial control to a more liberalized financial sector (Marius \& Bogdan, 2012). This became phenomenal in the late 1990s. For instance the control of domestic banks by foreign banks increased from $1.6 \%$ in 1994 to $6 \%$ in $1999,7.5 \%$ to $25 \%$ during the same period and $8 \%$ in 1994 to $52 \%$ in 1999 for south-east Asia, Latin America and Eastern Europe respectively (IMF, 2000, p. 153).

For some years now the Ghanaian banking system has witnessed some amount of regulatory changes in its operations. Among these current developments are the introduction of Universal Banking License in 2003, which permitted banks with GHC 70 billion in capital to carry out any form of banking. In 2004, The Banking Act 2004 (Act, 673) replaced the banking Law 1989 (PNDCL, 225), while the Foreign Exchange Act 2006 (Act, 723) and the Whistleblowers Act 2006 (Act, 720) were passed in 2006. The Credit Reporting Act 2007 (Act, 726 ) and the Banking (Amendment) Act 2007 (Act, 738) were passed into effect in 2007, while the Borrowers and Lenders Act, 2008 (Act, 773), the Non-Banking Financial Institutions Act, 2008 (Act, p. 774), the Home Mortgage Finance Act, 2008 (Act, p. 770) and the Anti-money Laundering Act, 2008 (Act, 749) were passed in 2008, including a directive to banks to comply with International Financial Reporting Standards (IFRS). Following the passage of these acts and reforms, foreign-owned banks have increased their presence and intensified their operations in Ghana by setting up more branches and networks. The influx of these foreign banks raises questions about their impact on the operations of domestic banks. The current study does not only empirically examines effect of foreign banks presence on the operations of domestic banks in Ghana but it also examines the stands that in emerging market economies, foreign banks perform better than their domestic counterparts.

The rest of the paper is organized as follows: The next session provides a review of related literature. Section three describes the data and methodology. Section four discusses the results of the empirical analysis and section five summarizes the findings and concludes the study. 


\section{Related Literature Review}

The increased presence of foreign banks and their contributions to the operations of domestic banks remains a contentious and sensitive issue. Several research works have been conducted on the potential benefits and cost of foreign bank entry on the operations of domestic bank. Barajas et al. (2000) point out that in Columbia, foreign bank entry is associated with competition Notwithstanding, the increased competition among the domestic banks have also led to a high rate of non-performing loans hence the intermediation process. Feldstein (2000) also found that, inspite of the increased competition as a result of foreign bank entry, domestic Korean banks are denied in sharing their risk management techniques. The study further reveals that lack of these risk management technique often results in domestic banks having a high non- performing loans. In Central and Eastern European Countries, Poghosyan (2010) shows that foreign banks' participation do not have any significant effects on profitability. Detragiache et al. (2008) and Lin (2011) show that less opaque firms and non- state-owned firms benefit more from foreign bank entry. Their findings further suggest that firms with higher value of potential collateral do not benefits with foreign bank presence. Denizer (2000) confirms that Turkey's domestic bank's overheads and return on assets decrease after foreign bank entry.

Having considered a numerous cost associated with foreign bank entry, several studies have also highlighted the benefits of foreign bank entry on domestic banks operation (see, for instance, Levine, 1996; Walter \& Gray, 1983; Goldberg \& Saunders, 1981). Unite and Sullivan (2003) and Peria and Mody (2003) note that foreign banks entry forces the domestic banks to be more focus, efficient and independent on relationship-based banking practices. In Indonesia Cho (1990) also found that foreign banks entry induces competition in the banking industry. In Australia, McFadden (1994) found that the improved operations of domestic banks are as a result of foreign bank entry. This position is supported by Xu (2011).The study findings reveal that in China, foreign bank entry leads to a more competitive and efficient banking industry. Lin and Zeng (2013) provide further empirical works on the behavior of domestic banks in China after the entry foreign of banks and indicate that domestic banks reduce transaction fees and service fees shortly before the entry of foreign banks into China, but did not reduce the same fees after the entry of foreign banks, indicating that an opposite relationship between entry of foreign banks and incumbents' pricing in the Chinese banking market. Peek and Rosengren (2000) note that the introduction of new technology and management by foreign bank subsidiaries has been of great benefits to the domestic banks. Simpasa (2013) study extends previous research and suggests that pressures in the operations of domestic banks are often as a result of foreign bank penetration and privatization. Foreign banks are mostly active in their home countries and are likely to infest host banking markets with improved information technologies (Focarelli \& Pozzolo, 2000). Theoretically, foreign entry can influence banks in host countries through various direct and indirect channels and increase competition (see, Lehner \& Schnitzer, 2008, Levine 1996; Glaessner \& Oks, 1994). From an industrialized countries point of view Sturm and Williams (2004) document that foreign banks perform better.

Chantapong (2005) found that foreign banks generate more profits than domestic bank. According to Micco et al. (2004), foreign banks tend to perform better than their domestic counterparts (see also DeYong \& Nolle, 1996; Bonin et al., 2005). In contrast, Kosmidou et al. (2004) found that domestic banks perform better than foreign banks in terms of net interest margin, pre-tax profits and reported less loan loss provisions. Research on US data indicates that foreign banks perform significant worse than domestic banks (see, for example DeYoung \& Nolle, 1996; Mahajan et al., 1996). Vander Vennet (1996) also finds no differences in profitability between foreign and domestic banks. However, Mian (2003), Nikiel and Opiela (2002) and Yildirim and Philippatos (2007) find the opposite or no significant difference between domestic and foreign banks.Lensink and Hermes (2004) found that the effect of foreign bank entry depends on the level of economic development in the host country. Sabi (1996) findings did not support the claim that domestic banks performs well because of foreign bank presence. The results reported by Zhu (2011) show that, on average, foreign bank entry in developing countries is not immediately associated with greater cost efficiency. Whether foreign entry leads to greater financial intermediation efficiency is not conclusive. Empirical evidence regarding the entry of foreign bank on domestic banks' operations is quite limited and mixed and inconclusive. Therefore the cost and benefits should be the country in question (Briones \& Villela, 2006).

The following research gaps have been revealed in the literature review. The related literature review reveals rather indifferent and inconclusive of effects of foreign bank entry on the operations of domestic banks. Again, several of these studies were conducted using the developed economies for example US and Europe where the impact may differ. Finally, in the Sub-Saharan countries like Ghana such studies are rare. Two studies which covered Ghana were Figueira et al. (2006) and Damoah (2013). Whereas former included 16 banks in his study, the latter study focused on the manufacturing sector of the economy. However, banks in Ghana are over 27 with 
a substantial foreign presence. A major gap in the literature is providing new empirical evidence to examine the effects of foreign banks entry on the operations of domestic banks.

\section{Description of Data and Methodology}

The study employs data drawn mainly from financial statements of 27 commercial banks (both foreign and domestic banks) in Ghana for the period, 1997-2014. Data for GDP, inflation and real interest were obtained from Ghana Statistical Service (GSS) and Bank of Ghana (BOG) respectively. In examining the effects of foreign banks entry on the operations of domestic banks, the study introduces variables that measure the presence of foreign banks found in a domestic country in terms of share and assets and this ratio is represented

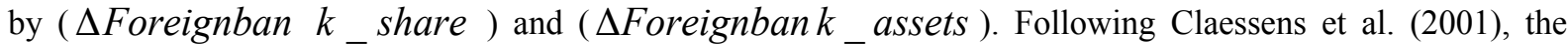
study further construct variables reflecting domestic bank behavior and in terms of income, and costs of domestic banks. Two variables representing income of banks are the Net interest rate income to total assets (NII) and Non-interest income to total assets (NOII). Overhead costs to total assets (OVTA) and Non performing loan to total assets (NPLTA) represent the cost variables. A variation in these variables would be as a result of changes in foreign bank presence through competition. The model for empirical investigation can be stated as follows:

$$
\Delta \Pi_{i t}=a_{0}+\beta \Delta \text { Foreignbank_share }_{t}+\gamma \Delta B S C_{i t}+\delta \Delta M E C_{t}+\varepsilon_{i t}
$$

Where $\Delta \Pi_{i t}$ is the dependent variable (Return on Assets) for bank $i$ at time $t ; \Delta$ Foreignbank_share $_{t}$ is a share of foreign banks at time $t$ and reflects the intensity of foreign banks' presence. $B S C_{i t}^{-}$is a set of bank-specific control variables for the bank $i$ at time $t$; and $\triangle M E C_{t}$ is a set of macroeconomic control variables for the commercial bank $i$ at time t. The study defined a bank as foreign only when it has at least. A bank is defined $50 \%$ of its shares is foreign owned. The following bank-specific characteristics of bank are used: (i) net interest income/total assets, (ii) non-interest income/ total assets, (iii) return on assets, (iv) overhead/ total assets, (v) non-performing loans, (vi) deposits/ total assets, (vii) liquidity/ total assets, (viii) age/market experience, (ix) bank size, and (x) capital/ total assets. The country- specific characteristics adopted in the study are: annual growth rate of (xi) GDP (GROWTH), (xii) annual inflation rate (consumer prices) (INFL), and (xiii) real interest rate. Definition, measurement and expected relationship of the selected variables of this study are reported in Table 1.

Table 1. Variable definition and expected relationship variable

\begin{tabular}{|c|c|c|c|c|c|c|c|}
\hline \multirow[t]{2}{*}{ Variables } & \multirow[t]{2}{*}{ Definition } & \multicolumn{6}{|c|}{ Expected Relationship to Panels } \\
\hline & & $\mathrm{P} 1$ & $\mathrm{P} 2$ & $\mathrm{P} 3$ & $\mathrm{P} 4$ & P5 & P6 \\
\hline \multicolumn{8}{|l|}{ Dependable Variables } \\
\hline ROA & Return on assets & $\mathrm{n} / \mathrm{a}$ & $\mathrm{n} / \mathrm{a}$ & $\mathrm{n} / \mathrm{a}$ & $\mathrm{n} / \mathrm{a}$ & $\mathrm{n} / \mathrm{a}$ & $\mathrm{n} / \mathrm{a}$ \\
\hline \multicolumn{8}{|l|}{ Independable Variables } \\
\hline$\Delta$ Foreignbank_share & $\begin{array}{l}\text { Number of foreign } \\
\text { banks to the total } \\
\text { number of domestic } \\
\text { banks }\end{array}$ & - & - & + & + & + & + \\
\hline$\Delta$ Foreignban $k_{-}$assets & $\begin{array}{l}\text { Share of foreign } \\
\text { bank assets to total } \\
\text { bank assets of the } \\
\text { domestic country }\end{array}$ & - & - & + & + & + & + \\
\hline \multicolumn{8}{|l|}{ Internal factors } \\
\hline OVTA & $\begin{array}{l}\text { Overhead to total } \\
\text { assets }\end{array}$ & & & & & & - \\
\hline DEPTA & $\begin{array}{l}\text { Deposits to total } \\
\text { assets }\end{array}$ & & & & & & $+/-$ \\
\hline NPLTA & $\begin{array}{l}\text { Non-performing } \\
\text { loans/Total Loans }\end{array}$ & & & & & & - \\
\hline LIQ & $\begin{array}{l}\text { Liquidity to total } \\
\text { assets }\end{array}$ & & & & & & $+/-$ \\
\hline AGE & Age/Experience & & & & & & + \\
\hline
\end{tabular}




\begin{tabular}{lll}
\hline BKSZ & Bank Size & + \\
CTA & Capital/Total assets & +
\end{tabular}

\section{External factors}

$\begin{array}{ll}\text { GDPG } & \begin{array}{l}\text { Gross Domestic } \\ \text { Product Growth } \\ \text { Inflation }\end{array} \\ \text { INFL } & \text { Real interest rate }\end{array}$

Note. P1 represents Panel 1(Net Interest), P2 is Panel 2 (Non-Interest income), P3 is Panel 3 (Return on Assets), P4 represents Panel 4 (Overheads), P5 is also Panel 5 (Non-Performing) and P6 is Panel 6(GDP growth).

Table 2 documents the proportion of foreign Banks in domestic banking system in terms of both foreign banks share and assets.

Table 2. Proportion of Foreign Banks in domestic banking system: 1997-2014

\begin{tabular}{llll}
\hline Year & No. of foreign banks in total & No. of foreign banks assets in total & Total No. of banks \\
\hline 1997 & 0.33 & 0.52 & 15 \\
1998 & 0.36 & 0.54 & 14 \\
1999 & 0.36 & 0.57 & 14 \\
2000 & 0.44 & 0.58 & 16 \\
2001 & 0.41 & 0.51 & 17 \\
2002 & 0.39 & 0.49 & 18 \\
2003 & 0.39 & 0.49 & 18 \\
2004 & 0.39 & 0.49 & 18 \\
2005 & 0.42 & 0.60 & 19 \\
2006 & 0.52 & 0.64 & 23 \\
2007 & 0.48 & 0.52 & 23 \\
2008 & 0.48 & 0.52 & 23 \\
2009 & 0.52 & 0.55 & 25 \\
2010 & 0.52 & 0.53 & 25 \\
2011 & 0.52 & 0.52 & 27 \\
2012 & 0.56 & 0.57 & 25 \\
2013 & 0.52 & 0.59 & 27 \\
2014 & 0.50 & 0.56 & 28 \\
Averages & 0.43 & 0.54 & 21 \\
\hline
\end{tabular}

From Table 2, apart from the drop experienced in 2002 to 2004 in terms of both foreign banks share and assets, the share of foreign bank assets exceeds the number of domestic banks assets. This is also the case for a simple average of all the years under review.

Table 3 presents the bank spread and profitability between 1997-2014 periods. An ownership indicator of "F" refers to the group of foreign banks and "D" refers to the group of domestic banks. In column 3, 4 and 8 these accounting ratios in fact report significantly higher ratios than domestic banks between 2004-2014. This was because Ghana experienced a high influx of foreign banks for the period 1992-2008 coupled with several regulatory changes the financial sector witnessed. In column 5, domestic banks dominate a large share of overhead expenses to total assets. The increase in employment as well as total amount of wages and salaries could be an attempt of avoiding pouching of staffs by these foreign banks and this causes extra cost to be incurred in protecting their market share. Column 6 reflects the corporate income tax in the domestic country. Foreign banks turn to contribute more than the domestic banks as a share of assets at about $70 \%$ of the taxes paid by all banks during the period under review. Column 7 displays significantly lower provisioning ratios for 
foreign banks. This is a result of foreign bank ability to identify bad loans and their zero tolerance for loan provisions.

Table 3. Bank spread and profitability: foreign VRS domestic 1997-2014

\begin{tabular}{|c|c|c|c|c|c|c|c|}
\hline Year & Ownership & $\mathrm{NII}$ & NOII & OVTA & TAX & NPLTA & ROA \\
\hline \multirow[t]{2}{*}{1997} & $\mathrm{~F}$ & 0.56 & 0.22 & 0.32 & - & - & 0.31 \\
\hline & $\mathrm{D}$ & 0.85 & 0.74 & 0.95 & - & - & 0.46 \\
\hline \multirow[t]{2}{*}{1998} & $\mathrm{~F}$ & 0.61 & 0.21 & 0.34 & 0.14 & 0.20 & 0.46 \\
\hline & $\mathrm{D}$ & 0.86 & 0.53 & 0.77 & 0.14 & 0.09 & 0.52 \\
\hline \multirow[t]{2}{*}{1999} & $\mathrm{~F}$ & 0.49 & 0.20 & 0.30 & 0.12 & 0.03 & 0.23 \\
\hline & $\mathrm{D}$ & 0.67 & 0.59 & 0.69 & 0.12 & 0.12 & 0.32 \\
\hline \multirow[t]{2}{*}{2000} & $\mathrm{~F}$ & 0.76 & 0.35 & 0.68 & 0.14 & 0.07 & 0.17 \\
\hline & $\mathrm{D}$ & 0.71 & 0.81 & 0.64 & 0.11 & 0.26 & 0.63 \\
\hline \multirow[t]{2}{*}{2001} & $\mathrm{~F}$ & 0.72 & 0.37 & 0.55 & 0.14 & 0.07 & 0.29 \\
\hline & $\mathrm{D}$ & 1.41 & 0.75 & 1.02 & 0.18 & 0.33 & 0.62 \\
\hline \multirow[t]{2}{*}{2002} & $\mathrm{~F}$ & 0.50 & 0.41 & 0.48 & 0.11 & 0.10 & 0.24 \\
\hline & $\mathrm{D}$ & 0.72 & 0.62 & 0.88 & 0.07 & 0.34 & 0.07 \\
\hline \multirow[t]{2}{*}{2003} & $\mathrm{~F}$ & 0.49 & 0.52 & 0.47 & 0.10 & 0.07 & 0.17 \\
\hline & $\mathrm{D}$ & 0.73 & 0.68 & 0.80 & 0.08 & 0.26 & 0.22 \\
\hline \multirow[t]{2}{*}{2004} & $\mathrm{~F}$ & 1.82 & 0.59 & 0.46 & 0.09 & 0.06 & 0.24 \\
\hline & $\mathrm{D}$ & 0.83 & 1.10 & 0.83 & 0.10 & 0.24 & 0.30 \\
\hline \multirow[t]{2}{*}{2005} & $\mathrm{~F}$ & 0.61 & 0.36 & 0.66 & 0.10 & 0.08 & 0.18 \\
\hline & $\mathrm{D}$ & 0.92 & 0.51 & 0.90 & 0.09 & 0.26 & 0.24 \\
\hline \multirow[t]{2}{*}{2006} & $\mathrm{~F}$ & 0.78 & 0.44 & 1.02 & 0.09 & 0.08 & 0.00 \\
\hline & $\mathrm{D}$ & 0.73 & 0.44 & 0.77 & 0.06 & 0.15 & 0.18 \\
\hline \multirow[t]{2}{*}{2007} & $\mathrm{~F}$ & 0.60 & 0.44 & 0.77 & 0.66 & 0.09 & 0.12 \\
\hline & $\mathrm{D}$ & 0.78 & 0.47 & 0.88 & 0.07 & 0.13 & 0.22 \\
\hline \multirow[t]{2}{*}{2008} & $\mathrm{~F}$ & 0.42 & 0.23 & 0.75 & 0.09 & 0.10 & 0.23 \\
\hline & $\mathrm{D}$ & 0.49 & 0.06 & 1.02 & 0.07 & 0.22 & 0.06 \\
\hline \multirow[t]{2}{*}{2009} & $\mathrm{~F}$ & 0.50 & 0.11 & 0.17 & 0.13 & 0.34 & 0.11 \\
\hline & $\mathrm{D}$ & 0.41 & 0.09 & 0.13 & 0.07 & 0.20 & 0.09 \\
\hline \multirow[t]{2}{*}{2010} & $\mathrm{~F}$ & 0.87 & 0.44 & 0.12 & 0.12 & 0.17 & 0.20 \\
\hline & $\mathrm{D}$ & 0.95 & 0.34 & 0.09 & 0.09 & 0.29 & 0.22 \\
\hline \multirow[t]{2}{*}{2011} & $\mathrm{~F}$ & 0.87 & 0.60 & 0.83 & 0.16 & 0.11 & 0.41 \\
\hline & $\mathrm{D}$ & 0.84 & 0.59 & 0.98 & 0.07 & 0.17 & 0.26 \\
\hline \multirow[t]{2}{*}{2012} & $\mathrm{~F}$ & 1.08 & 1.22 & 0.83 & 3.11 & 0.16 & 1.01 \\
\hline & $\mathrm{D}$ & 0.80 & 0.49 & 0.76 & 0.28 & 0.20 & 0.27 \\
\hline \multirow[t]{2}{*}{2013} & $\mathrm{~F}$ & 0.99 & 0.51 & 0.69 & 0.20 & 0.14 & 0.19 \\
\hline & $\mathrm{D}$ & 0.99 & 0.56 & 0.09 & 0.11 & 0.15 & 0.41 \\
\hline \multirow[t]{2}{*}{2014} & $\mathrm{~F}$ & 1.18 & 0.60 & 0.80 & 0.25 & 0.12 & 0.64 \\
\hline & D & 0.94 & 0.58 & 0.98 & 0.11 & 0.11 & 0.33 \\
\hline
\end{tabular}

Notation (F) represents a bank with foreign ownership and (D) represents domestic bank.

\section{Empirical Results}

Table 4 provides the descriptive of all the selected variables used in the study. The mean values of variables indicate that domestic banks, on average have $8.03 \%$ net interest income $5.14 \%$ of non-interest income per total assets and an average of $-2.76 \%$ of return on assets. The banking sector over the eighteen years of study, had on average $6.34 \%$ of the overhead expenses per total assets; $67.33 \%$ of deposits per total assets; $17.91 \%$ of liquidity per total assets, $1.33 \%$ of non-performing loans per total loans and market experience of twenty-seven years. On average, the bank size is GHS 902,150.16 for the 18 years period. Banks' capital per total assets records $15.52 \%$ on average. The foreign banks share in the Ghanaian market contribute on average 46 percent of the total banks shares of the sample period. The average variability over the period is eight percent with a minimum share of 33 percent and maximum share of 60 percent. The foreign bank asset to total bank assets contributes 46 percent on average over the eighteen years period. 
GDP growth, inflation and real interest rate register average rates $6.55 \%, 16.03 \%$ and $21.22 \%$ respectively. Standard deviation of variables show that a very slight variations were found in the dataset these are deposits to total assets, liquidity to total assets, age/market experience and capital to total assets.

Table 4. Summary statistics

\begin{tabular}{lcccc}
\hline Variables & Mean & Std Dev. & Min & Max \\
\hline NII & 8.03 & 7.49 & 0.62 & 134.52 \\
NOII & 5.14 & 4.13 & 0.38 & 62.19 \\
ROA & -2.76 & 6.12 & -67.79 & 48.22 \\
Foreign Banks Share & 46.00 & 8.00 & 33.00 & 60.00 \\
Foreign bank asset & 46.00 & 9.00 & 33.00 & 65.00 \\
OVTA & 6.34 & 3.25 & 3.51 & 0.00 \\
DEPTA & 67.33 & 25.92 & 1.37 & 84.49 \\
NPL & 1.33 & 1.56 & 14.43 & 1.45 \\
LIQ & 17.91 & 13.78 & 2.04 & 152.66 \\
AGE & 27.02 & 28.89 & 0.00 & 86.00 \\
BKSZ & $902,150.16$ & $1,347,377.00$ & 15.38 & $7,792,016.00$ \\
CTA & 15.52 & 14.17 & 0.00 & 188.78 \\
GDP Growth & 6.55 & 2.87 & 3.63 & 15.27 \\
INFL & 16.03 & 7.31 & 8.33 & 40.64 \\
RIR & 21.22 & 8.85 & 12.50 & 45.00 \\
\hline Note. Th & & & \\
\hline
\end{tabular}

Note. The table presents the summary statistics of the variables used in the regression analysis.

Regression equations estimates of the six panel models are displayed in table 5. A diagnostic test was carried out to identify if the specified models are valid. The overall significance of the model is fully supported by the statistical significance of the F-test. The study fails to reject the null hypothesis of the White's-test in all the six models, which reveals that the residuals are white noise and there is no presences of hetroscedasticity in the independent variables.

The results reveal that foreign bank share is significantly associated with increase in net interest income (Panel 1) and returns on assets (Panel 3). Foreign bank share seems to have direct effect on non-interest income margin (Panel 2) and negative effects on overheads per total assets (Panel 4), non-performing loans (Panel 5) and GDP growth (Panel 6). Nevertheless, the results do not indicate any statistically significant relationship with these variables. This indicates that foreign bank entry is associated with an increase in domestic banks profitability and this may be as result of increasing competitive conditions. The research did not reveal any significant association of overhead and non-performing loans with foreign bank entry, indicating that foreign bank entry is associated with greater efficiency in the operations of domestic banks systems.

The results also revealed that, foreign bank asset to total bank assets significantly related to the decrease in Net interest income (Panel 1), Non-interest income (Panel 2) and Returns on assets (Panel 3). The foreign bank asset to total bank assets show inverse effect with Non-performing loans (Panel 5) and direct effect with Overheads (Panel 4) and GDP growth (Panel 6) but the effects are not statistically significant at any level of significance.

Focusing on the control variables, the results show that with the exception of deposit, liquidity and capital which are positively associated significantly with profitability; the other remaining factors did not reveal any statistical significance at any level. The result is interpreted to mean that higher deposits, liquidity and capital will increase profitability of domestic banks. These findings affirm the research work of (Acheampong, 2013) and contrary to the findings of (Claessens et al., 2001).

Macroeconomic control variables results indicate that there is an inverse relationship between GDP growth on one hand and net interest income and overhead expenses on the other hand confirming the finding Claessens et al. (2001), and contrary to (Denizer, 1999). This clearly demonstrates that Ghanaian banks do not respond immediately to economic declines by reducing overheads. Contrary to earlier studies, the findings reveal that in boom periods for the economy, several opportunities may elude the banks to increase their net interest incomes.

Another factor likely to affecting the costs and revenue of banks is Inflation. Staikouras and Wood (2003) note that inflation may have direct and indirect influence on the profitability of banks. Real interest rate is statistically significant with net interest income, non-interest income return on assets and negatively associated with 
overheads and GDP growth.

Table 5. Regression results on change in foreign bank presence and change in domestic bank performance

\begin{tabular}{|c|c|c|c|c|c|c|}
\hline Variables & $\Delta \mathrm{NII}$ & $\Delta$ NOII & $\Delta \mathrm{ROA}$ & $\Delta$ OVTA & $\Delta \mathrm{NPL}$ & $\Delta \mathrm{GDP}$ G \\
\hline \multirow{2}{*}{ Constant } & 2.790 & 1.085 & 1.256 & -1.604 & -0.475 & $8.577 * * *$ \\
\hline & $(0.744)$ & $(0.549)$ & $(0.418)$ & $(-1.037)$ & $(-0.613)$ & (7.705) \\
\hline Foreign & $7.283 * * *$ & 1.827 & $5.064 * * *$ & -0.426 & -1.145 & -0.216 \\
\hline \multicolumn{7}{|l|}{ Banks share } \\
\hline & $(2.946)$ & $(0.700)$ & (2.779) & $(-0.209)$ & $(-1.121)$ & $(-0.136)$ \\
\hline \multirow{2}{*}{$\begin{array}{l}\Delta \text { Foreign Bank } \\
\text { assets }\end{array}$} & $-4.272 * *$ & $-2.379 * *$ & $-5.213 *$ & 0.610 & -1.191 & 1.018 \\
\hline & $(-2.021)$ & $(-2.132)$ & $(-2.308)$ & $(0.349)$ & $(-1.362)$ & $(0.750)$ \\
\hline \multirow[t]{2}{*}{$\Delta$ OVTA } & -0.145 & $-0.182 * * *$ & 0.040 & - & $-0.049^{*}$ & $-0.116^{* * *}$ \\
\hline & $(-1.113)$ & $(-2.657)$ & $(0.381)$ & - & $(-1.805)$ & $(-2.798)$ \\
\hline \multirow[t]{2}{*}{$\triangle \mathrm{DEPTA}$} & $0.052 * * *$ & $0.018^{*}$ & $-0.204^{* * *}$ & -0.005 & -0.005 & 0.005 \\
\hline & $(2.874)$ & (1.853) & $(-14.13)$ & $(-0.726)$ & $(-1.337)$ & $(0.886)$ \\
\hline \multirow[t]{2}{*}{$\Delta \mathrm{LIQ}$} & 0.028 & $0.066^{* * *}$ & $0.065^{* *}$ & $-0.049 * * *$ & $-0.017 * *$ & $0.025^{* *}$ \\
\hline & $(0.736)$ & $(3.301)$ & (2.13) & $(-3.215)$ & (2.135) & $(-2.09)$ \\
\hline \multirow[t]{2}{*}{$\Delta \mathrm{AGE}$} & 0.005 & 0.008 & -0.008 & 0.009 & 0.000 & 0.006 \\
\hline & $(0.322)$ & $(0.885)$ & $(-0.607)$ & (1.286) & $(0.014)$ & (1.145) \\
\hline \multirow[t]{2}{*}{$\Delta \mathrm{BKSZ}$} & 0.000 & 0.000 & 0.000 & $-5.357 * * *$ & 0.000 & 0.000 \\
\hline & $(0.030)$ & $(0.383)$ & (1.837) & $(-3.886)$ & (1.295) & $(-1.31)$ \\
\hline \multirow[t]{2}{*}{$\Delta \mathrm{CTA}$} & $0.063^{* *}$ & $0.033^{*}$ & $0.132 * * *$ & 0.007 & $-0.015^{* *}$ & $0.035^{* * *}$ \\
\hline & (1.982) & (1.947) & $(5.162)$ & $(0.502)$ & $(-2.23)$ & (3.38) \\
\hline \multirow[t]{2}{*}{$\Delta \mathrm{GDP}$} & $-0.275^{* * *}$ & 0.018 & 0.106 & $-0.191 * * *$ & 0.055 & - \\
\hline & $(-3.285)$ & $(0.206)$ & $(0.793)$ & $(-2.798)$ & (1.601) & - \\
\hline \multirow[t]{2}{*}{$\Delta \mathrm{INFL}$} & -0.025 & 0.023 & 0.021 & $-0.100 * * *$ & 0.019 & $-0.192 * * *$ \\
\hline & $(-0.344)$ & $(0.614)$ & $(0.365)$ & $(-3.446)$ & (1.323) & $(-9.393)$ \\
\hline \multirow[t]{2}{*}{$\Delta \mathrm{RIR}$} & $0.128^{*}$ & $0.082 * * *$ & $0.15^{* *}$ & $-0.113^{* *}$ & 0.019 & $-0.194 * * *$ \\
\hline & $(2.15)$ & $(2.41)$ & $(3.65)$ & $(-5.286)$ & $(1.56)$ & $(-11.61)$ \\
\hline Adj. R2 & 0.237 & 0.136 & 0.162 & 0.171 & 0.098 & 0.356 \\
\hline F-Statistic & 2.585 & 5.342 & 3.833 & 5.948 & 2.886 & 15.942 \\
\hline (P- Value) & 0.002 & 0.000 & 0.000 & 0.000 & 0.001 & 0.000 \\
\hline \multirow{2}{*}{$\begin{array}{l}\text { White-test } \\
\text { (P-value) }\end{array}$} & 0.185 & 0.089 & 0.530 & 2.120 & 2.540 & 3.140 \\
\hline & 0.833 & 0.912 & 0.423 & 0.231 & 0.221 & 0.186 \\
\hline No. & 359 & 359 & 389 & 389 & 389 & 389 \\
\hline
\end{tabular}

Note. P1 represents Panel 1(Net Interest), P2 is Panel 2 (Non-Interest income), P3 is Panel 3 (Return on Assets), P4 represents Panel 4 (Overheads), P5 is also Panel 5 (Non-Performing) and P6 is Panel 6(GDP growth).

Values in parentheses are the t-statistic. * indicates significant at $10 \%$ level; ** indicates significant at $5 \%$ level; and $* * *$ indicates significant at $1 \%$ level.

\section{Conclusion}

Benefits of financial integration and liberalization have made banking markets rapidly becoming global .The study did not only examine the effects of entry of foreign banks on the operations of domestic banks in Ghana, but it also examines, to a large extend, the performance of foreign and domestic banks during the period, 1997-2014.

Results from the study indicate that competitions in the banking industry are usually as a result of the entry of foreign banks as shown by increasing profitability of banks. This seems to suggest that foreign banks presence is noted upon entry not when they have gained a huge market share. Management of the economy and policymakers should be aware of the timing and the implications in relaxing or tighting their regulatory policies. Host countries businesses tend to benefits more with credit from foreign banks when the macroeconomics climate is favorable. 
Although the result reveals that deposit is inversely related to profitability, liquidity and capital are directly related to profitability. The study further suggests that these bank- specific variables are statistically significant and impact greatly on the profitability of the Ghanaian banks. Nevertheless, variations in Ghanaian banks profitability are not explained statically by economic growth and inflation. Efficiency, profitability, and competitiveness are a major ingredient of a continued success of the Ghanaian banking sector. In maximizing the benefits of foreign bank entry, policy-makers and managers should consider critically the timing of the financial integration and liberalization process and ensure adequate regulations.

Our results failed to investigate that the mode of foreign bank entry is an essential factor determining bank performance. The future research direction following this study is not only to investigate the mode of entry of foreign banks on bank performance but also to add qualitative factors, for example, management leadership style with the quantitative factors and test the long-run effects using a cointegration approach.

\section{References}

Acheampong, N. K. (2013). The effects of foreign bank entry on financial performance of domestic-owned banks in Ghana. The International Journal of Business and Finance Research, 7(3), 93-104.

Barajas, A., Salazar, N., \& Steiner, R. (2000). Foreign investment in Colombia's financial sector. In S. Claessens, M. Jansen, (Eds.), The Internationalization of Financial Services: Issues and Lessons for Developing Countries. Dordrecht: Kluwer Academic Press. http://dx.doi.org/10.2139/ssrn.218069

Berger, A. N. (1995). The relationship between capital and earnings in banking. Journal of Money, Credit and Banking, 27, 432-456. http://dx.doi.org/10.2307/2077877

Bonin, J. P., Hasan, I., \& Wachtel, P. (2005). Bank performance, efficiency and ownership in transition countries. Journal of Banking and Finance, 29, 31-53. http://dx.doi.org/10.1016/j.jbankfin.2004.06.015

Briones, I., \& Villela, A. (2006). European bank penetration during the first wave of globalization: Lessons from Brazil and Chile. European Review of Economic History, 10(3), 329-345. http://dx.doi.org/10.1017/S136149160600178X

Caprio, G. J., \& Summers, L. H. (1993). Finance and its reform: Beyond laissez-faire. Policy Research. Washington, D.C.: The World Bank. Working Paper No. 1171

Chantapong, S. (2005). Comparative study of domestic and foreign bank performance in Thailand: The regression analysis. Economic Change and Restructuring, 38(1), 63-83. http://dx.doi.org/10.1007/s10644-005-4523-5

Cho, K. R. (1990). Foreign banking presence and banking market concentration: The case of Indonesia. The Journal of Development Studies, 27(1), 891-911. http://dx.doi.org/10.1080/00220389008422185

Claessens, S., Demirguc-Kunt, A., \& Huizinga, H. (2001). How does foreign entry affect domestic banking markets? Journal of Banking and Finance, 25(5), 891-911. http://dx.doi.org/10.1016/S0378-4266(00)00102-3

Damoah, O. B. O. (2013). Strategic factors and firm performance in an emerging economy. African Journal of Economic and Management Studies, 4(2), 267-287. http://dx.doi.org/10.1108/AJEMS-02-2013-0013

Demirguct-Kunt, A., \& Huizinga, H. (1999). Determinants of commercial banks interest margins and profitability: Some international evidence. The World Bank Econometric Review, 13(2), 379-408. http://dx.doi.org/10.1093/wber/13.2.379

Denizer, C. (1999). Foreign entry in Turkeys banking sector, 1980-1997. Unpublished manuscript, IFC/World Bank.

Denizer, C. (2000). Foreign Bank Entry in Turkey's Banking Sector, 1980-1997. In S. Claessens, \& M. Jansen (Eds.), The Internationalisation of Financial Services: Issues and Lessons for Developing Countries. Dordrecht: Kluwer Academic Press.

Detragiache, E., Tressel, T., \& Gupta, P. (2008). Foreign banks in poor countries: theory and evidence. Journal of Finance, 63(5), 2123-2160. http://dx.doi.org/10.1111/j.1540-6261.2008.01392.x

DeYong, R., \& Nolle, D. (1996). Foreign-owned banks in the US: Earning domestic bank behaviour: Does economic development matter? Journal of Banking and Economic Activity, 2, 23-158.

Domanski, D. (2005). Foreign banks in emerging market economies: Changing players, changing issues. BIS Quarterly Review, December, 69-81. 
Feldstein, M. (2000). Discussion Summary Version of May 17, 2001, Financial Policies, Economic and Financial Crisis in Emerging Markets Economies, NBER Conference, October 19-21, Woodstock, Vermont.

Figueira, C., Nellis, J., \& Parker, D. (2006). Does ownership affect the efficiency of African banks? The Journal of Developing Areas, 40(1), 38-63. http://dx.doi.org/10.1353/jda.2007.0004

Focarelli, D., \& Pozzolo, A. F. (2000). The Determinants of Cross-Border Shareholding: An Analysis with Bank-Level Data from OECD Countries. Paper presented at the Federal Reserve Bank of Chicago Bank Structure Conference.

Glaessner, T., \& Oks, D. (1994). NAFTA, Capital Mobility, and Mexico's Financial system. Unpublished paper, World Bank. Retrieved from http://www.bog.gov.gh/

Goldberg, L. G., \& Saunders, A. (1981). The discriminants of foreign banking activity in the US. Journal of Banking, 50, 1377-1420.

Havrylchyk, O. (2012). The effect of foreign bank presence on firm entry and exit in transition economies. Journal of Banking and Finance, 36(6), 1710-1721. http://dx.doi.org/10.1016/j.jbankfin.2012.01.015

International Monetary Fund. (2000). International Capital Markets: Developments, Prospects and Key Policy Issues. IMF, Washington, DC.

Kosmidou, K., Pasiouras, F., Doumpos, M., \& Zopounidis, C. (2004). Foreign versus domestic banks' performance in the UK: A multicriteria approach. Computational Management Science, 1, 329-343. http://dx.doi.org/10.1007/s10287-004-0019-4

Lehner, M., \& Schnitzer, M. (2008). Entry of foreign banks and their impact on host countries. Journal of Comparative Economics, 36(3), 430-452. http://dx.doi.org/10.1016/j.jce.2008.02.002

Lensink, R., \& Hermes, N. (2004). The short-term effects of foreign bank entry on domestic bank behaviour: Does economic development matter? Journal of Banking and Finance, 3(28), 553-568. http://dx.doi.org/10.1016/S0378-4266(02)00393-X

Levine, R. (1996). Foreign banks, financial development and economic growth. In H. Cheng (Ed.), International Financial Markets. Washington, D.C.: AEI Press.

Lin, H. (2011). Foreign bank entry and firms' access to bank credit: Evidence from China. Journal of Banking and Finance, 35(4), 1000-1010. http://dx.doi.org/10.1016/j.jbankfin.2010.09.015

Lin, H. C., \& Zeng, T. (2013). Domestic banks \& apos; responses to the entry of foreign banks in China. Journal of Chinese Economic and Foreign Trade Studies, 6(3), 168-177. http://dx.doi.org/10.1108/JCEFTS-03-2013-0008

Mahajan, A., Rangan, N., \& Zardkoohi, A. (1996). Cost structures in multinational and domestic banking. Journal of Banking and Finance, 20, 238-306. http://dx.doi.org/10.1016/0378-4266(94)00129-4

Marius, A. A., \& Bogdan, C. (2012). Impact of Financial Liberalization on Banking Sector Performance.

McFadden, C. (1994). Foreignbanks in Australia. The World Bank, Mimeo.

Mian, A. (2003). Foreign, Private Domestic and Government Banks: New Evidence from Emerging Markets. University of Chicago, Mimeo.

Micco, A., Panizza, U., \& Yanez, M. (2004). Bank ownership and performance. Inter-American Development Bank. Washington, D.C., AEI Press. http://dx.doi.org/10.2139/ssrn.1818718

Miller, S. M., \& Eden, L. (2006). Local density and foreign subsidiary performance. The Academy of Management Journal, 49(2), 341-355. http://dx.doi.org/10.5465/AMJ.2006.20786081

Miller, S. M., \& Noulas, A. (1997). Portfolio mix and large bank profitability in the USA. Applied Economics, 29, 505-512. http://dx.doi.org/10.1080/000368497326994

Nikiel, E. M., \& Opiela, T. P. (2002). Customer type and bank efficiency in Poland: Implications for emerging market banking. Contemporary Economic Policy, 20, 255-271. http://dx.doi.org/10.1093/cep/20.3.255

Peek. J., \& Rosengren, E. (2000). Implications of the globalization of the banking sector: The Latin American experience. New England Economic Review, 45-62.

Peria, M. S., \& Mody, A. (2003). How foreign participation and market concentration impact bank spreads: Evidence from Latin America. Journal of Money, Credit and Banking, 36(3), 511-537. 
Poghosyan, T. (2010). Re-examining the impact of foreign bank participation on interest margins in emerging markets. Emerging Markets Review, 11(4), 390-403. http://dx.doi.org/10.1016/j.ememar.2010.08.003

Sabi, M. (1996). Comparative analysis of foreign and domestic bank operations in Hungary. Journal of Comparative Economics, 22(2), 179-188. http://dx.doi.org/10.1006/jcec.1996.0017

Simpasa, A. M. (2013). Increased foreign bank presence, privatization and competition in the Zambian banking sector. Managerial Finance, 39, 787-808. http://dx.doi.org/10.1108/MF-May-2010-0076

Staikouras, C., \& Wood, G. (2003,). The determinants of bank profitability in Europe. Paper presented at the European Applied Business Research Conference, June 9-13Venice, Italy.

Sturm, J. E., \& Williams, B. (2004). Foreign bank entry, deregulation and bank efficiency: Lessons from the Australian experience. Journal of Banking and Finance, 28, 1775-1799. http://dx.doi.org/10.1016/j.jbankfin.2003.06.005

Unite, A., \& Sullivan, M. J. (2003). The effect of foreign entry and ownership structure on the Philippine domestic banking market. Journal of Banking and Finance, 27, 2323-2345. http://dx.doi.org/10.1016/S0378-4266(02)00330-8

Vander, V. R. (1996). The effect of mergers and acquisitions on the efficiency and profitability of EC credit institutions. Journal of Banking and Finance, 20, 1531-1558. http://dx.doi.org/10.1016/S0378-4266(96)00014-3

Walter, I., \& Gray, H. P. (1983) Protectionism, and international banking, sectoral efficiency, competitive structure and national policy. Journal of Banking and Finance, 7, 597-609. http://dx.doi.org/10.1016/0378-4266(83)90019-5

$\mathrm{Xu}, \mathrm{Y}$. (2011). Towards a more accurate measure of foreign bank entry and its impact on domestic banking performance: The case of China. Journal of Banking and Finance, 35(4), 886-901. http://dx.doi.org/10.1016/j.jbankfin.2010.10.011

Yildirim, H. S., \& Philippatos, G. C. (2007). Efficiency of banks: Recent evidence from the transition economies of Europe, 1993-2000. European Journal of Finance, 31, 123-143. http://dx.doi.org/10.1080/13518470600763687

Zhu, L. (2011). Impact of foreign entry on banks' operating efficiency: The role of the pre-existing competitive environment in emerging markets. Advances in Competitive Research, 19, 100-119.

\section{Copyrights}

Copyright for this article is retained by the author(s), with first publication rights granted to the journal.

This is an open-access article distributed under the terms and conditions of the Creative Commons Attribution license (http://creativecommons.org/licenses/by/3.0/). 